\section{Guidelines for Grazing Sheep on Rangelands Used by Big Game in Winter ${ }^{1}$}

\section{CHARLES H. JENSEN, ARTHUR D. SMITH, AND GEORGE W. SCOTTER}

Game Biologist, Utah Division of Wildlife Resources, Logan; Project Leader, Utah State Division of Wildlife Resources and Professor of Range Science, Utah State University, Logan; and Research Biologist, Canadian Wildlife Service, Edmonton, Alberta.

\section{Highlight}

A big game winter range in northen Utah was grazed with domestic sheep to ascertain what seasons and intensity of use would maximize utilization of herbs and minimize utilization of shrubs which provide the majority of forage for big game in winter, thus minimizing forage competition between big game and sheep. In late spring and early summer sheep ate mostly herbs. The light utilization of shrubs resulted in little or no reduction in forage production by shrubs at the end of the growing season. After midJuly, sheep heavily utilized bitterbrush (Purshia tridentata), the most desirable and abundant shrub for big game in this area. Grazing after mid-July reduced the volume of bitterbrush forage available for big game proportionately to the percentage utilization observed. There was no evidence that subsequent annual productivity of cstablished plants was impaired by any of the grazing systems imposed.

For range managers, no problem is more critical than that of properly allocating forage on ranges frequented by big game in winter and domestic livestock at other times of the year, usually in spring and fall. These ranges typically constitute the weak link in forage for big game and commonly set the upper limit on big game populations.

The problem has two main facets. First, single use grazing patterns tend to cause trends from one type of vegetation to another. Second, big game and livestock may be in direct competition for the same forage plants even though time of occupancy may be different.

If trends occur under single use, they are usually toward a less desirable vegetative mix for the animal singly using the range. On a northern Utah range big game use alone caused a reduction in shrubs and an increase in herbs; spring use by domestic livestock coupled with winter use by big game reduced herbs and increased shrubs (Smith, 1949). At the U.S. Sheep Station near Dubois, Idaho, spring sheep grazing or a combination of spring and fall sheep grazing of sagebrush-grass rangcland resulted in an increase of three-tip sagebrush (Artemisia tripartita) ${ }^{2}$ and a decrease of grasses and forbs. Heavy fall sheep use maintained

${ }^{1}$ A contribution of Federal Aid Project PRW-105-R. Received October 13, 1971.

${ }^{2}$ Nomenclature follows Holmgren and Reveal, 1966. a vigorous cover of herbaceous plants with sagebrush forming an open stand among them (Laycock, 1967; Craddock and Forsling, 1938).

In northern Utah utilization of bitterbrush (Purshia tridentata) by cattle was inconsequential prior to July 1, but substantial thereafter. Cows consumed primarily grasses and secondarily forbs. Clipping of herbaceous vegetation during the growing season significantly increased yields of bitterbrush plants and demonstrated that cattle grazing before July 1 caused little competition for forage between cattle and big game (Smith and Doell, 1968). Such findings suggest that vegetation may be manipulated by controlling livestock use to maintain or increase forage production by desirable shrubs. There is support for this in the work reported by others (Ferguson and Basile, 1968; Garrison, 1953; and Neff, 1964).

The objectives of this study were to determine the forage preferences of domestic sheep throughout the summer and to identify the seasons and intensities of use which would hold forage competition with big game to an acceptable level.

\section{Study Area and Procedures}

The study was conducted on big game winter range at the state-owned Hardware Ranch near Logan, Utah, between 5,700 and 6,200 feet elevation. The vegetation is a sagebrush-grass type, although shrubs and herbaceous vegetation alternately dominate specific sites. Grasses, forbs, and shrubs provide about equal amounts of forage. Annual plants are of little importance, except in years with abundant summer precipitation.

Soils are of the Ant Flat and Yeates Hollow series (Doell, 1966). Average annual precipitation is about 16 inches. The frost-free period is usually from mid-June to mid-August lasting about 100 days, although in 1969 temperatures lower than $30 \mathrm{~F}$ were observed in every summer month (U.S. Dept. of Commerce).

From 1967 through 1969, twelve pastures approximately three acres in size were grazed by dry and yearling Columbia ewes during six different periods between May 20 and October 15 and at two intensities within each period. Beginning dates for grazing were approximately May 20, June 20, July 15, August 10, September 5, and October 1 each year; there was no late May period in 1967. Each pair of pastures was grazed during the same period, but intensities were alternated cach ycar.

In 1967, the two grazing intensities were set at $40 \%$ (moderate) and $70 \%$ (heavy) utilization of the assumed key species, Pacific aster (Aster chilensis) and arrowleaf balsamroot (Balsamorhiza sagittata). In the late June and late July periods, grazing was terminated when these intensities of use were attained. In subsequent periods the pastures were grazed for 108 and 189 sheep days per pasture for moderate and heavy intensities respectively to achieve comparable intensities of use.

The 1967 data showed highly variable utilization values which appeared to be primarily due to differences in amounts of forage produced in individual pastures by the key species. Accordingly, intensities of use in 1968 and 1969 were assigned on the basis of pregrazing estimates of "usable forage" 
Table 1. Sheep days use per acre and acres per AUM for two grazing intensities (\%) and six grazing periods, 19671969 .

\begin{tabular}{lccrrrr}
\hline \hline \multicolumn{1}{c}{ Season } & $\begin{array}{c}\text { Projected } \\
\text { intensity } \\
\text { of use }\end{array}$ & $1967^{\mathrm{a}}$ & 1968 & 1969 & Mean & $\begin{array}{c}\text { Acres } \\
\text { AUM }^{\mathrm{b}}\end{array}$ \\
\hline Late May & 40 & - & 41 & 38 & 39.5 & 3.8 \\
& 70 & - & 59 & 88 & 73.5 & 2.0 \\
Late June & 40 & 35 & 49 & 58 & 47.3 & 3.2 \\
& 70 & 59 & 94 & 87 & 80.0 & 1.9 \\
Late July & 40 & 41 & 53 & 51 & 48.3 & 3.1 \\
& 70 & 75 & 85 & 93 & 84.3 & 1.8 \\
Mid-August & 40 & 35 & 60 & 43 & 46.0 & 3.3 \\
& 70 & 59 & 102 & 72 & 77.7 & 1.9 \\
Mid-September & 40 & 37 & 56 & 53 & 48.7 & 3.1 \\
& 70 & 58 & 101 & 87 & 82.0 & 1.8 \\
Early October & 40 & 36 & 65 & 60 & 53.7 & 2.8 \\
& 70 & 68 & 94 & 108 & 90.0 & 1.7 \\
Mean & 40 & 36.8 & 54.0 & 50.5 & 47.2 & 3.2 \\
& 70 & 63.8 & 89.2 & 89.2 & 81.2 & 1.8 \\
\hline
\end{tabular}

"There was no late May grazing in 1967.

${ }^{b}$ Based on five dry ewes to an Animal Unit.

production. Species which were observed to be of low palatability to sheep in 1967 were excluded from total forage production-big sagebrush (Artemisia tridentata), low sagebrush ( $A$. arbuscula), and mulesears wyethia (Wyethia amplexicaulis) for all grazing periods and bluebunch wheatgrass (Agropyron inerme) after late July. A daily forage requirement of $3 \mathrm{lb}$./animal was assumed. Moderate use was set at $40 \%$ utilization and heavy use at $70 \%$ utilization of usable forage. The total sheep days allotted each pasture was determined before sheep were placed in the pastures by multiplying the total usable forage in each pasture by the desired utilization percentage and dividing by three.

The sheep herd was divided between the two pastures of each pair so that the length of the grazing period would be the same in each. Grazing periods for the pairs of pastures lasted from 8-16 days.

Weight estimates (Pechanec and Pickford, 1937a) were made in 50 circular plots of two sizes-96 $\mathrm{ft}^{2}$ in the case of bitterbrush and $9.6 \mathrm{ft}^{2}$ for all other species. Both plots were permanent and centered on the same stake. Utilization of all species other than bitterbrush was determined by ocular estimates (Pechanec and Pickford, 1937b) in the same plots upon completion of grazing.

Utilization of bitterbrush was obtained from measuring the twigs on four branches on each of 50 plants within each pasture (Smith and Urness, 1962). Since there was little or no current year's twig growth in May and June, the previous year's growth was measured. Thereafter, only current growth was considered.

In 1968 and 1969, in areas adjacent to the pastures, thirty bitterbrush plants were selected to determine the rate of twig growth when unaffected by sheep grazing. Current twigs on four marked branches per plant were measured at weekly intervals from the time twig elongation began in late May or early June until growth rate decreased in midAugust. Thereafter, measurements were made twice each year.

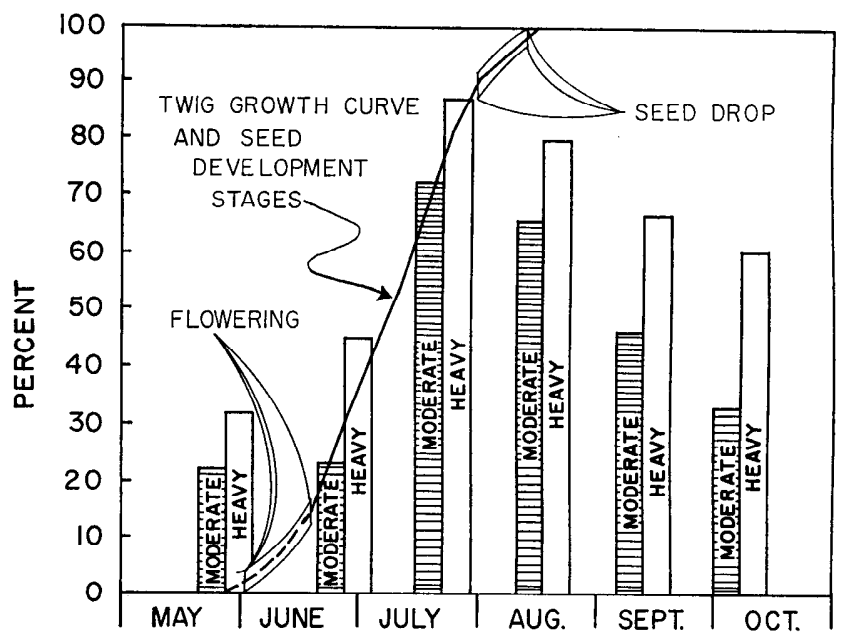

Fic. 1. Three year average utilization of bitterbrush under two grazing intensities compared to stages of growth.

Phenological data for the principal plant species were recorded at intervals throughout the summer.

\section{Results \\ Grazing Intensities}

The three-acre pastures provided 35 to 65 sheep days per acre under moderate grazing and 58 to 108 sheep days per acre under heavy grazing (Table 1). Based on a conversion ratio of five sheep to an AU (animal unit), the pastures carried from 0.23 to 0.70 AUMs (animal unit months) per acre or, conversely, requircd 4.3 acres to 1.3 acres/AUM. There was no evidence that the intensities imposed caused changes in composition of vegetation, although changes have been reported in this length of time under spring grazing (Laycock, 1967). Grazing intensities were alternated between paired pastures each year which may have obscured the effects of intensity. Consequently, there is no assurance that the heavy intensity would be permissible every year.

\section{Phenology of Bitterbrush}

Growth on unbrowsed bitterbrush plants was observed about May 1, 1968 in the enlargement of leaves. Numerous flower buds were evident by June 1 and plants had reached full flower about June 12. Growth of twigs began concurrently with the full flowering stage and rate of elongation was nearly constant through a seven-week period ending on about August 1, when 91\% of the season's total twig growth was attained. Growth rate of twigs then declined and elongation was not detected after August 15 (Fig. 1). Seed matured and abscised coincident with the slowing of growth between August 1 and August 15 much as reported from California (Hormay, 1943). 
reached about three weeks earlier than in 1968, except for completion of twig elongation which was about one week later.

Browsing either by sheep in summer or by big game in winter altered phenological stages and growth patterns. Leaves started growth about one week later and twig elongation began about ten days earlier than on unbrowsed plants, but the times of flowering and seed cast were unaffected. Browsing substantially reduced flower and seed production and increased twig growth.

\section{Utilization of Shrubs}

Utilization of bitterbrush was comparatively light in late May and only slightly heavier in late June (Table 2). There was little use of the year-old twigs which were measured in these periods. Sheep picked off the leaves and bud clusters from older growth without reducing the length of twigs; consequently twig measurements at this time did not accurately indicate actual utilization.

Heavy use of bitterbrush was first observed in July when twig growth was rapid and herbaceous plants were drying. Utilization declined somewhat in August, September, and October. However, the lighter utilization in October reduced bitterbrush forage by one-third when moderately used and about two-thirds when heavily used.

In addition to differences in intensity of use, there were differences in the way sheep browsed

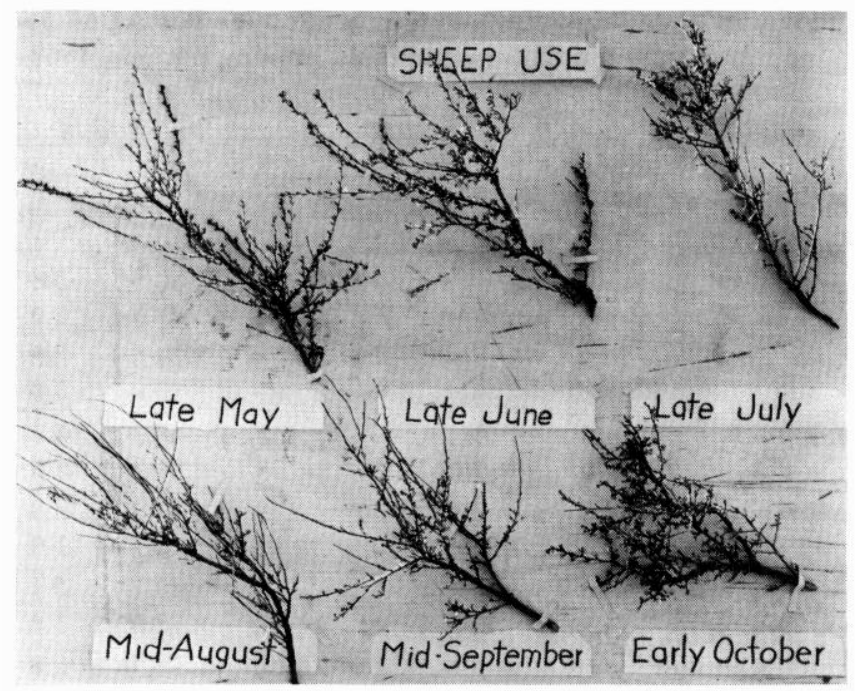

FIG. 2. Selected branches of bitterbrush as they appeared at the end of the growing season showing these distinctive grazing patterns: May and June-abundant regrowth; July-complete twig removal without regrowth; August-stripped twigs; September-twigs both stripped and clipped; October-partial twig removal.

from period to period which left distinctive marks (Fig. 2). Plants browsed by sheep in late May and late June or by big game in winter were characterized by numerous shoots and large volumes of forage by the end of the growing season. In late July sheep consumed most of the current year's growth.

Table 2. Three year mean utilization of important plants by sheep during six periods and two intensities on a northern

Utah foothill rangeland 1967-1969.

\begin{tabular}{|c|c|c|c|c|c|c|c|c|c|c|c|c|}
\hline \multirow[b]{2}{*}{ Species } & \multicolumn{6}{|c|}{ Moderate intensity } & \multicolumn{6}{|c|}{ Heavy intensity } \\
\hline & $\begin{array}{l}\text { Late } \\
\text { May }\end{array}$ & $\begin{array}{l}\text { Late } \\
\text { June }\end{array}$ & $\begin{array}{l}\text { Late } \\
\text { July }\end{array}$ & $\begin{array}{l}\text { Mid- } \\
\text { Aug. }\end{array}$ & $\begin{array}{l}\text { Mid- } \\
\text { Sept. }\end{array}$ & $\begin{array}{c}\text { Early } \\
\text { Oct. }\end{array}$ & $\begin{array}{l}\text { Late } \\
\text { May }\end{array}$ & $\begin{array}{l}\text { Late } \\
\text { June }\end{array}$ & $\begin{array}{l}\text { Late } \\
\text { July }\end{array}$ & $\begin{array}{l}\text { Mid- } \\
\text { Aug. }\end{array}$ & $\begin{array}{l}\text { Mid- } \\
\text { Sept. }\end{array}$ & $\begin{array}{c}\text { Early } \\
\text { Oct. }\end{array}$ \\
\hline \multicolumn{13}{|l|}{ Grasses } \\
\hline Bluebunch wheatgrass & 4 & 2 & 2 & 1 & 1 & 1 & 16 & 4 & 9 & 3 & 7 & 5 \\
\hline Prairie Junegrass & 20 & 16 & 25 & 31 & 48 & 50 & 30 & 40 & 44 & 48 & 58 & 64 \\
\hline Kentucky bluegrass & 30 & 17 & 20 & 25 & 39 & 39 & 48 & 34 & 42 & 47 & 49 & 60 \\
\hline Sandberg bluegrass & 27 & 10 & 25 & 9 & 12 & 28 & 50 & 5 & 42 & 10 & 25 & 47 \\
\hline \multicolumn{13}{|l|}{ Forbs } \\
\hline Western yarrow & 4 & 17 & 5 & 7 & 11 & 1 & 16 & 18 & 17 & 14 & 25 & 22 \\
\hline Pacific aster & 37 & 32 & 53 & 56 & 50 & 40 & 72 & 61 & 77 & 66 & 72 & 61 \\
\hline Arrowleaf balsamroot & 21 & 22 & 10 & 42 & 20 & 8 & 42 & 71 & - & 57 & 55 & 23 \\
\hline Bushy birdbeak & - & 15 & 24 & 43 & 14 & 17 & - & 57 & 74 & 42 & 51 & 47 \\
\hline Fremont geranium & 0 & 4 & 4 & - & - & 5 & 0 & 17 & 17 & - & - & 10 \\
\hline One-flower helianthella & 40 & - & 75 & 42 & 24 & 67 & 68 & - & 0 & 49 & 45 & - \\
\hline Stoneseed & 30 & - & - & 58 & 35 & - & 70 & - & - & 74 & 72 & 15 \\
\hline Tailcup lupine & 29 & 15 & 61 & 60 & 58 & 41 & 26 & 61 & 79 & 65 & 75 & 67 \\
\hline Slender cinquefoil & - & 8 & 33 & - & - & 40 & - & 31 & 50 & - & - & 54 \\
\hline Mulesears wyethia & 31 & 5 & 4 & - & 0 & 4 & 95 & 16 & 11 & 3 & 32 & - \\
\hline \multicolumn{13}{|l|}{ Shrubs } \\
\hline Saskatoon serviceberry & - & 36 & 40 & 55 & 55 & 0 & - & 73 & 61 & 70 & 70 & 4 \\
\hline Yellowbrush & 0 & 2 & 6 & 6 & 4 & 12 & 2 & 24 & 38 & 14 & 24 & 30 \\
\hline Bitterbrush & 22 & 23 & 72 & 65 & 46 & 33 & 32 & 45 & 87 & 80 & 66 & 60 \\
\hline
\end{tabular}


Such heavily browsed plants did not produce regrowth and appeared to lack vigor. In August, and to a lesser extent in September, sheep stripped bitterbrush twigs of leaves and bark and left the woody xylem exposed. Few twigs were nipped off as they had been earlier and as they were again in October. Whatever the use pattern, plants browsed after midJuly did not produce regrowth.

Shrubs other than bitterbrush were relatively unimportant sources of forage due to infrequency of occurrence or low palatability to sheep. Big sagebrush, low sagebrush, and yellowbrush accounted for $51 \%$ or more of the available shrub forage in the various pastures. The two sagebrushes were little utilized, if at all. The less abundant yellowbrush (Chrysothamnus viscidiflorus) provided some forage after the late May period but was not a preferred species (Table 2). Saskatoon serviceberry (Amelanchier alnifolia) was heavily utilized but produced such small amounts of forage that inferences about its palatability to sheep are hazardous except in October when it was lightly utilized indicating low palatability at that season.

\section{Utilization of Grasses}

Utilization of grasses was variable. Kentucky bluegrass (Poa pratensis) was one of the more preferred plants, but following seed maturity in late June and July utilization decreased (Table 2). Seasonal utilization of Sandberg bluegrass (Poa secunda) and prairie Junegrass (Koeleria cristata) was similar to that of Kentucky bluegrass. Sandberg bluegrass seed matured and seed stalks dried about June 25. Prairie Junegrass and Kentucky bluegrass reached those stages about July 15. In the fall these species produced green regrowth when soil moisture was adequate. Consequently, utilization of these grasses was comparatively heavy during early September and early October periods.

Use of most other grasses did not reach the assigned utilization intensities in any period. All species of the tribe Triticeae including Great Basin wildrye (Elymus cinereus), bluebunch wheatgrass, western wheatgrass (Agropyron smithii), and squirreltail (Sitanion hystrix) along with oniongrass (Melica bulbosa) were lightly used especially as the season advanced. Annual bromes (Bromus tectorum and $B$. japonicus) received negligible use during any growth stage under either intensity.

\section{Utilization of Forbs}

Forbs were important in all periods but most species showed marked seasonal differences in palatability. Pacific aster alone maintained a relatively high palatability, and it was utilized at approximately the assigned intensities (40\% and $70 \%)$ in all grazing periods. Better than any other plant, it qualified as a key species in this vegetative mix irrespective of its abundance or its season of use (Table 2).

Arrowleaf balsamroot was utilized most heavily in the early periods although utilization of it was erratic (Table 2). Much of the utilization observed after the late June period may have been due to trampling of dried stems and leaves. Similarly, mulesears wyethia was utilized heavily in late May with utilization decreasing in late June and becoming negligible after mid-July. This decline in

Table 3. Average percent of sheeps diet and percent composition by forage classes for two intensities and six grazing periods at Hardware Ranch (1967-1969).

\begin{tabular}{|c|c|c|c|c|c|c|c|c|c|}
\hline \multirow[b]{2}{*}{ Use period } & \multirow[b]{2}{*}{ Intensity } & \multicolumn{2}{|c|}{ Grasses } & \multicolumn{2}{|c|}{ Forbs } & \multicolumn{2}{|c|}{ Shrubs } & \multicolumn{2}{|c|}{ Bitterbrush $^{1}$} \\
\hline & & $\%$ diet & $\%$ comp. & $\%$ diet & $\%$ comp. & $\%$ diet & $\%$ comp. & $\%$ diet & $\%$ comp. \\
\hline \multirow[t]{2}{*}{ Late May $^{2}$} & Moderate & 25.9 & 29.3 & 68.3 & 40.1 & 5.6 & 30.6 & 5.3 & 2.6 \\
\hline & Heavy & 23.0 & 26.0 & 73.7 & 46.9 & 3.4 & 27.1 & 3.0 & 2.5 \\
\hline \multirow{2}{*}{ Late June } & Moderate & 23.4 & 20.2 & 58.0 & 33.7 & 18.5 & 46.1 & 9.6 & 4.4 \\
\hline & Heavy & 19.7 & 17.6 & 58.1 & 38.4 & 22.2 & 44.0 & 12.4 & 5.1 \\
\hline \multirow[t]{2}{*}{ Late July } & Moderate & 19.7 & 20.4 & 51.9 & 53.1 & 28.4 & 26.5 & 23.5 & 4.0 \\
\hline & Heavy & 26.1 & 22.6 & 52.5 & 17.1 & 21.4 & 30.0 & 16.2 & 3.8 \\
\hline \multirow[t]{2}{*}{ Mid-August } & Moderate & 11.2 & 40.0 & 61.0 & 29.8 & 27.8 & 30.2 & 24.0 & 6.7 \\
\hline & Heavy & 8.9 & 31.8 & 63.7 & 35.3 & 27.4 & 32.9 & 21.9 & 7.6 \\
\hline \multirow[t]{2}{*}{ Mid-September } & Moderate & 17.3 & 41.5 & 59.9 & 36.5 & 22.8 & 22.0 & 21.0 & 8.5 \\
\hline & Heavy & 17.1 & 42.7 & 57.9 & 33.4 & 25.0 & 23.9 & 22.0 & 10.1 \\
\hline \multirow[t]{2}{*}{ Mid-October } & Moderate & 26.8 & 16.5 & 50.2 & 34.6 & 23.0 & 48.9 & 20.8 & 11.0 \\
\hline & Heavy & 25.3 & 18.4 & 45.7 & 34.0 & 28.9 & 47.6 & 22.8 & 10.6 \\
\hline \multirow[t]{2}{*}{ Period averages } & Moderate & 20.6 & 28.0 & 58.3 & 38.0 & 21.1 & 34.0 & 17.3 & 6.2 \\
\hline & Heavy & 20.0 & 26.5 & 58.6 & 39.2 & 21.4 & 34.3 & 16.3 & 6.6 \\
\hline Average & & 20.3 & 27.2 & 58.5 & 38.6 & 21.2 & 34.2 & 16.8 & 6.3 \\
\hline
\end{tabular}

${ }^{1}$ Included in shrub total.

${ }^{2}$ Only two year's data. 
consumption of mulesears wyethia started when the pungent odor it emits became evident-about two weeks before the full flower stage. Except for the seed heads, it was not eaten in the later periods, but the dry leaves were trampled to a mulch.

One-flower helianthella (Helianthella uniflora) was one of the more abundant and preferred plants in late May. Its absence or scarcity in the paddocks grazed in later periods does not permit any conclusive inference about its palatability seasonlong, although such amounts as were present in the pastures grazed in mid-August and mid-September were avidly eaten. It was a relished plant for sheep in northern Utah (Smith and Gaufin, 1950).

Tailcup lupine (Lupinus caudatus) was largely ignored prior to the flowering stage, but it was a highly preferred species during flowering and fruiting stages. Young plants which did not produce seeds were not usually eaten.

When they were present in the pastures, stoneseed (Lithospermum ruderale) and slender cinquefoil (Potentilla gracilis) were relished by sheep. Salsify (Tragopogon spp.) was palatable up until September, and bastard toadflax (Commandra umbellata) was heavily utilized seasonlong.

Western yarrow (Achillea millefolium) was present in all pastures and usually provided some forage, although it was not a preferred plant. Occasionally flower heads and possibly basal leaves were eaten, although the readiness with which they pull free at the leaf axil leaves little evidence of use. Fremont geranium (Geranium fremontii) was largely ignored in all periods.

Several other forbs were utilized by sheep but their infrequency in the pastures prevents positive inferences about their seasonal desirability to sheep. Bushy birdbeak (Cordylanthus ramosus), a late growing annual, was used in the later periods. However, its weak, brittle stem readily breaks at the ground surface, and its disappearance from sample plots may have been caused either by trampling or foraging. Columbia groundsel (Senecio integerrimus) was heavily utilized in late May but was unused after maturity.

\section{Contribution of Forage Classes to Sheep's Diet}

In all periods except late July, forbs contributed proportionally more to the diet than to production of forage- $58 \%$ as compared to $39 \%$ for all periods (Table 3 and Fig. 3). The reversal of the general trend in late July was attributed to the presence of large amounts of mulesears wyethia, which accounted for $35 \%$ and $26 \%$ of the forage produced under moderate and heavy intensities respectively but in each instance made up less than $15 \%$ of the diets.

With the exception of the mid-August and midSeptember periods of use, grasses were consumed
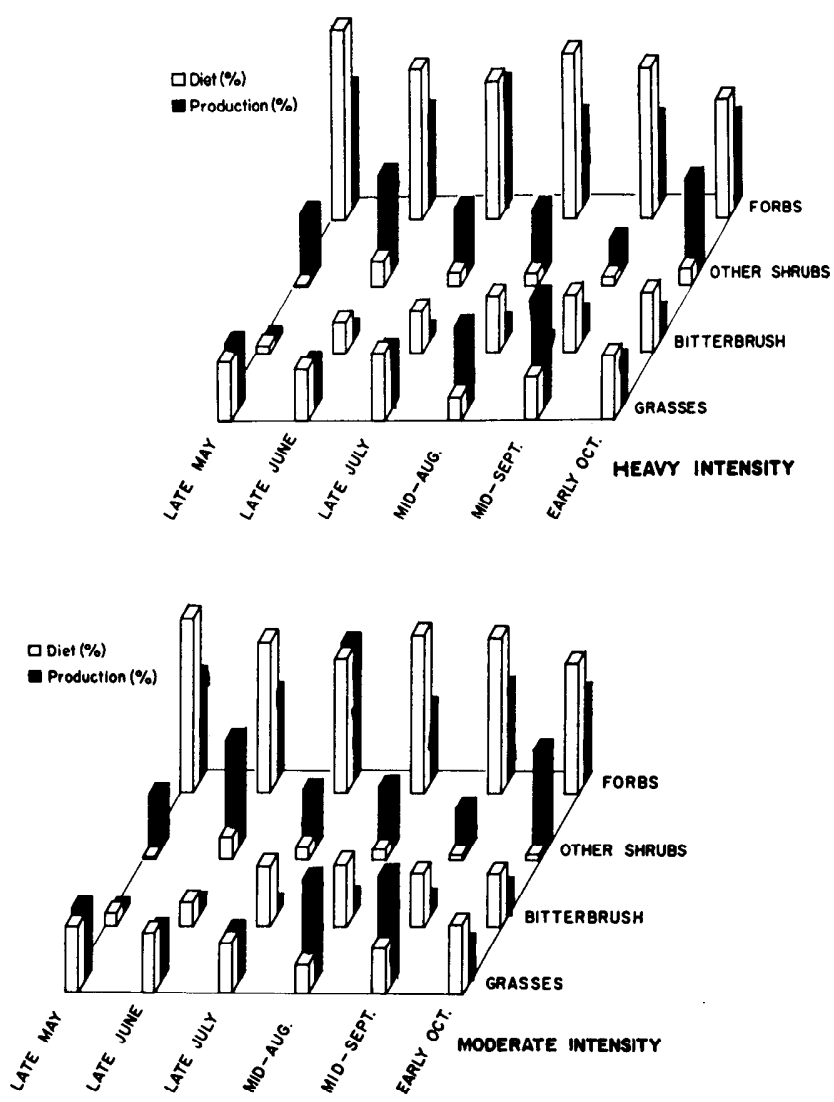

FIc. 3. Comparison of the proportions of available forage present and the proportions of each forage class in the diet of sheep under two grazing intensities.

approximately in proportion to their production of foragc (Fig. 3). However, the three most readily eaten grasses (Kentucky bluegrass, prairie Junegrass, and Sandberg bluegrass) were consistently more important in the diet than they were in terms of forage produced. In August and September bluebunch wheatgrass, a less palatable species, made up the bulk of the grass forage, hence grasses as a group appear less important than in other periods.

Bitterbrush made up a greater proportion of the seasonlong diet than of total forage (Fig. 3). The small contribution of bitterbrush to the diet in the May and June periods was primarily due to the fact that little new growth was present and measurement of the previous years' growth did not accurately measure use. Other shrubs contributed little forage to the diet, providing a maximum of about $6 \%$ of the sheep intake, even though they provided as much as $42 \%$ of the available forage.

\section{Amounts of Forage Consumed}

Daily forage intakes estimated from production and utilization data were 2.32 and 2.38 pounds (oven-dry) per animal daily for heavy and moderate intensities respectively, somewhat less than the three pounds assumed at the outset (Table 4). Con- 
Table 4. Daily forage intake (lb., oven-dry) per sheep during the six periods and two grazing intensities.

\begin{tabular}{|c|c|c|c|c|c|c|c|}
\hline \multirow{2}{*}{$\begin{array}{c}\text { Use } \\
\text { period }\end{array}$} & \multicolumn{3}{|c|}{ Heavy intensity } & \multicolumn{3}{|c|}{ Moderate intensity } & \multirow{2}{*}{$\begin{array}{c}\text { Period } \\
\text { mean }\end{array}$} \\
\hline & 1968 & 1969 & Mean & 1968 & 1969 & Mean & \\
\hline Late May & 1.21 & 1.91 & 1.56 & 1.32 & 1.24 & 1.28 & 1.42 \\
\hline Late June & 2.54 & 2.21 & 2.38 & 1.65 & 2.74 & 2.20 & 2.29 \\
\hline Late July & 2.48 & 2.62 & 2.55 & 3.13 & 2.12 & 2.62 & 2.58 \\
\hline Mid-Aug. & 2.19 & 2.38 & 2.28 & 2.87 & 3.07 & 2.97 & 2.62 \\
\hline Mid-Sept. & 2.94 & 2.66 & 2.80 & 2.92 & 2.61 & 2.76 & 2.78 \\
\hline Early Oct. & 2.41 & 2.28 & 2.34 & 2.91 & 2.07 & 2.49 & 2.41 \\
\hline Mean & & & 2.32 & & & 2.38 & 2.35 \\
\hline
\end{tabular}

sumption averaged only 1.42 pounds per day in late May, increased in each successive period to a maximum of 2.78 pounds in mid-September, and then dropped slightly in early October.

The smaller amounts of herbage consumed in the early periods are possibly explained by two factors. Plants were growing rapidly during May, and growth during the eight to ten day grazing periods was substantial which would tend to bias utilization figures downward. Second, forage produced in the early growth stages is more nutritious than later and sheep may have required less forage, dry weight. Consumption based upon field weights was as great or greater in the early grazing periods as in the later ones.

\section{Discussion}

Results indicate that sheep can use big game winter range without prohibitive use of bitterbrush and other shrubs, a possibility that previously had little support among many biologists. However, a range management plan geared to attaining or maintaining a high volume of browse forage for big game winter use must meet with the following requirements:

(1) Grazing periods must be timed so that utilization of shrubs by domestic livestock does not exceed acceptable levels.

(2) Herbaceous species must be utilized sufficiently to minimize competition with the shrubs.

(3) The time and intensity of use must be consistent with other rangeland uses and values.

Sheep grazing on big game winter ranges is compatible with big game use in this type of forage mix provided it is restricted to the early growing season before bitterbrush twigs are growing rapidly. Grazing should terminate approximately at the time bitterbrush sets seed which at this location occurred about June 15, in 1969 and July 1 in the two previous years.

After twigs have produced about one-third of their seasonal growth, about July 15 , even moderate sheep use will result in considerable loss of current year's production of bitterbrush. At Hardware Ranch this stage corresponds approximately to seed maturity of Kentucky bluegrass, prairie Junegrass, and balsamroots. Since, in this area, bitterbrush was the preferred shrub in all periods of spring, summer, and fall grazing, it is doubtful that other shrubs will be harmed by grazing if excessive utilization on bitterbrush is avoided.

Our results are similar to those obtained previously with cattle and reinforce the conclusion reached then, that livestock use on big game winter ranges is tolerable only during the early part of the plant growing season if maximum forage is to be retained for over-wintering game animals. After early June, sheep utilized bitterbrush more heavily than did cattle under similar conditions. The periods of heaviest sheep use were in July, August and September when little forage was left for game use. By contrast, even though use was heavy in October, considerable forage remained after sheep were removed. The heavy stripping of the current growth in August and September left an abundance of dry shoots that were unattractive as forage.

Sheep may be less effective than cattle in minimizing competition to shrubs from herbaceous plants. Their preference for forbs and reluctance to eat some grasses may not distribute grazing pressure adequately among the various components of the stand. This conclusion may be less valid in other areas where palatable grasses are more prominent, although the gradual conversion of vegetation toward grass under sheep use is a well known phenomenon. Ultimately it may be necessary to impose both cattle and sheep use in some systematic scheme in order to achieve the desired balance among various plant species in the stand.

Although restricting domestic livestock grazing to the early stages of bitterbrush growth is consistent with the outlined criteria for the short term, apprehension remains regarding the long term effects of continued single season use by livestock. Our data did not indicate any vegetative trends, although research results elsewhere indicate that vegetative changes are inherent under the influence of repeatedly grazing at a particular season. Consequently, pcriodic checks of vegetative composition of grazed and ungrazed areas should be made to make certain undesirable trends do not occur.

\section{Literature Cited}

Craddock, G. W., and C. L. Forsling. 1938. The influence of climate and grazing on spring-fall sheep range in southern Idaho. U.S. Dep. Agr. Tech. Bull. 600. 43 p. illus.

DoELL, D. D. 1966. Effects of summer cattle grazing on big-game winter range in northern Utah. Unpub. M.S. Thesis. Michigan State University. $55 \mathrm{p}$.

Ferguson, R. B., and J. V. Basile. 1968. Topping stimulates twig growth. J. Wildl. Manage. 30:339-341. 
Garrison, G. A. 1953. Effects of clipping on some range shrubs. J. Range Manage. 6:309-317.

Holmgren, A. H., and J. L. Reveal. 1966. Checklist of the vascular plants of the Intermountain Region. U.S. Forest Serv. Res. Paper INT.-32. 160 p.

HoRmay, A. L. 1943. Bitterbrush in California. U.S. Forest Serv., Calif. Forest and Range Exp. Sta. Res. Note 34. $12 \mathrm{p}$.

LAYCOCK, W. A. 1967. How heavy grazing and protection affects sagebrush-grass range. J. Range Manage. 20:206213.

NeFF. D. J. 1963. The effect of use on the vigor of browse plants. Job. Compl. Rep., Fed. Aid Project No. PRW78-R., Ariz. Game and Fish Dep. Processed. 8 p. + XII.

Pechanec, J. F., ANd G. D. Pickford. 1937a. A weight estimate method for the determination of range or pasture production. J. Amer. Soc. Agron. 29:894-904.

Pechanec, J. F., And G. D. Pickford. 1937b. A compari- son of some methods used in determining percentage utilization of range grasses. J. Agr. Res. 54:753-756.

Sмrтн, A. D. 1949. Effects of mule deer and livestock upon a foothill range in northern Utah. J. Wildl. Manage. 13:421-423.

Smith, A. D., and D. M. Gaufin. 1950. The use of movable paddocks in the study of forage preferences of mule deer and livestock. Tran. N. Am. Wildl. Conf. 15:512518.

Smith, A. D., AND D. D. Doell. 1968. Guides to allocating forage between cattle and big game on big game winter range. Utah State Div. of Fish and Game Publ. 68-11. $32 \mathrm{p}$.

Smith, A. D., ANd P. J. URness. 1962. Analysis of the twig length method of determining utilization of browse. Utah State Dept. of Fish and Game Publ. 62-9. $34 \mathrm{p}$.

U.S. Dept. Commerce. 1961-69. Climatological dataUtah Vols. 63-71. 